\title{
Beauty versus the beast
}

\section{Clare Elizabeth Caldwell}

Suspend belief for the next two minutes and imagine that you own a Ferrari Testarossa-a gleaming red marvel; the marriage of art and engineering. You and this breathtaking morsel of mechanistic beauty have been together for so long that you can't remember a time when you were not as one. You know each other intimately. Or do you?

One Sunday afternoon as you snake along the chicanes of a high mountainous road, the Testarossa emits a sickening bang. You pull the wheezing ball of exhaust fumes to the side of the road and pop the bonnet. When you lift the shining scarlet cranium and peer into the smoking beast, there is not a scintilla of recognition. You realise that you're looking at an entirely foreign being.

Now imagine that being is you.

For more than 2000 years, human beings have been peering under the bonnet of that metaphorical Testarossa. The ancient Greeks had a very good crack at unravelling the mysteries of the human mind and body well before the modern era. The Grecian physician Herophilus can take much of the credit, distinguishing the difference between motor and sensory nerves in around 280BC. But it is only within the last 200 years or so that significant leaps have been made in understanding the functions of the human body and the nuances and implications of those functions.

In this issue, Geoffrey Schott ${ }^{1}$ examines how French neurologist Guillaume Duchenne looked under that bonnet and made scientific and aesthetic discoveries that changed the world of neuroscience forever and continue to do so some 150 years later.

\section{GLinked}

- http://dx.doi.org/10.1136/jnnp-2012-302933

Correspondence to Clare Elizabeth Caldwell, Web Editor, JNNP, BMJ Publishing Group Ltd, BMA House, Tavistock Square, London WC1H 9JR, UK;

clarecaldwell@yahoo.com
As Schott discovered, Duchenne's Mécanisme ${ }^{2}$ received a cool reception when it was first published in 1862. However, the monograph went on to become a bible of facial anatomy, and in particular facial expression. In it, Duchenne claimed that each mental function correlated with a single particular muscle and its movement. Immersed in the minutiae of this study, the Frenchman focused his attentions on the corrugator supercilii-a small eyebrow muscle (figure 1).

Having introduced localised faradisation as a method of studying facial muscles in the 1850s, Duchenne employed his new techniques to illustrate how ancient Greek artists had used the humble corrugator supercilii to convey the emotion of pain. It seemed that the pre-Christian sculptors had made a valiant effort to capture the power of this tricky little muscle, but had not quite nailed it in their depiction of the Trojan priest, Laocoön, in about 100BC.

And it was not Duchenne alone who opined that the Greeks might have got it wrong. On revisiting the 19th Century Mécanisme, Schott confirms that other notable luminaries, including naturalist Charles Darwin and eminent surgeon Sir Charles Bell, concurred.

Duchenne concluded that, just as the Hellenistic sculptors before them had done, the Greco-Romans had erred in the name of beauty. And who could blame them?

So, as we return to our Testarossa, smouldering by the side of the road, we are again reminded of how often humans err in the pursuit of the sublime. Perhaps Duchenne would have gazed under the bonnet at the labyrinthine network of pumps and pistons and declared that the car's design was its Achilles' heel; that its elegance had impeded its performance. However, I suspect Schott may have assessed the same enigma and drawn a very different conclusion-that the inner workings had allowed for the supreme beauty of the outer shell, however flawed it may have been.

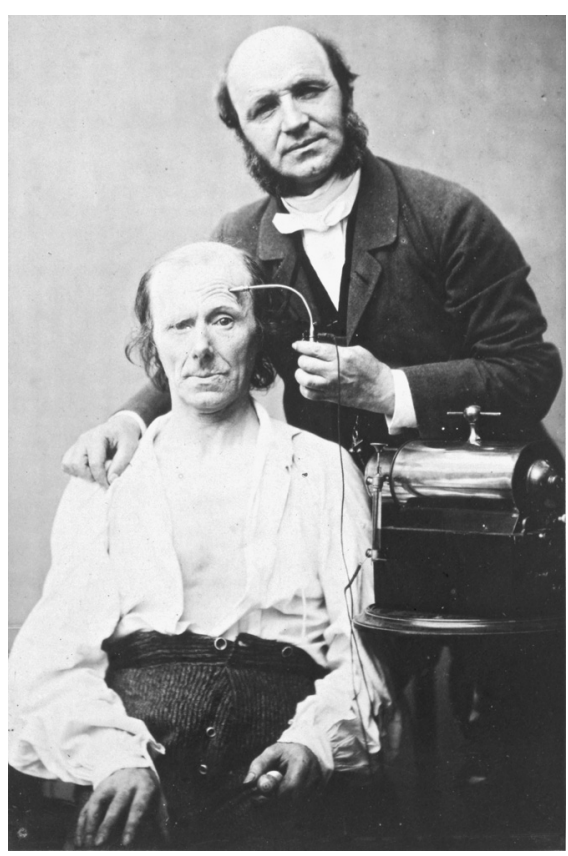

Figure 1 Faradisation Du Muscle Frontal Dr Guillaume Benjamin Amand Duchenne demonstrates his new neurophysiological methods in the 1850 s.

Competing interests None.

Provenance and peer review Commissioned; internally peer reviewed.

Received 28 June 2012

Accepted 30 June 2012

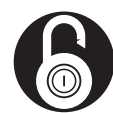

\section{OPEN ACCESS}

Open Access This is an Open Access article distributed in accordance with the Creative Commons Attribution Non Commercial (CC BY-NC 3.0) license, which permits others to distribute, remix, adapt, build upon this work non-commercially, and license their derivative works on different terms, provided the original work is properly cited and the use is non-commercial. See: http://creativecommons.org/licenses/by-nc/3.0/

Published Online First 31 July 2012

J Neurol Neurosurg Psychiatry 2013;84:3.

doi:10.1136/jnnp-2012-303300

\section{REFERENCES}

1. Schott GD. Duchenne superciliously 'Corrects' the Laocoön: sculptural considerations in the Mécanisme de la Physionomie Humaine. J Neurol Neurosurg Psychiatry 2013;84:10-13

2. Duchenne GB. Mécanisme de la physionomie humaine ou analyse électro-physiologique de ses différents modes de l'expression. Paris: archives générales de médecine, P Asselin. 1862. 